\title{
Plastic Pellets on Campeche Beach (Santa Catarina Island, Brazil): A Seasonality and Composition Study
}

\author{
Patrícia Louro*, Walter Martin Widmer \\ Federal Institute of Santa Catarina, Brazil
}

Copyright $\bigcirc 2017$ by authors, all rights reserved. Authors agree that this article remains permanently open access under the terms of the Creative Commons Attribution License 4.0 International License

\begin{abstract}
Alerts regarding marine contamination by microplastics motivated this study, conducted in Santa Catarina Island, South Brazil. During 12 sampling events, spatial and temporal distribution of plastic resin pellets, collected at two locations of Campeche beach, was analyzed, and polymer composition was identified. Plastic pellets were found in every sampling day, with a mean average of 1.16 pellets $/ \mathrm{m}^{2}$. Their abundance was influenced by two factors: Sampling location and Sampling day nested in each Season. There was a variable abundance along the monitoring period, with an increase of pellets in autumn. A significantly higher amount of pellets was found in one sampling place. The composition of the sampled pellets was heterogeneous, with a prevalence of low density polyethylene polymers. It is clear that a series of proceedings regarding production, stocking, transport and transformation of plastic pellets, must be considered, to avoid pellets loss of into the environment.
\end{abstract}

Keywords Beach, Brazil, Coastal Management, Marine Pollution, Microplastics, Monitoring, Pellets

\section{Introduction}

The Man's use of natural polymers such as horns, wax and resin for making artefacts is described since ancient times. From the XIX century on, thermoplastic production began to develop, initially as vulcanized rubber and polystyrene. Subsequently, other synthetic polymers such as poly (vinyl chloride) (PVC) and viscose [1] were developed. The manufacturing of synthetic polymers involves oil processing (the main raw material) with other materials such as cellulose, coal, salt, natural gas, along with various additives, such as antimicrobials, light and heat stabilizers, impact modifiers, fire retardants, plasticizers and pigments [2].

Plastics are a sub-category of polymers. Its low production cost and great versatility promote a continuous market growth, with the global production reaching 322 million tons [3]. Plastics are used for yogurt drinking bottles, clothing, furniture, surgical equipment, irrigation pipes, photovoltaic collectors, automobile and aircraft components, among several other examples. They cover a wide range of uses that satisfy certain concepts of development of the modern societies.

However, a huge amount of plastic items has short utility and it is improperly disposed of, accumulating in the marine environment [4], in gigantic "plastic soups" that gyre in the oceans, becoming habitat to bryozoans, polychaeta worms, hydroids and molluscs, which by nature could be carried by wooden pieces of volcanic floating rock fragments or adhered to ship hulls. In the port of Sydney, Australia, it was observed that $48 \%$ of the benthic waste consisted of plastic items, mostly incrusted by bryozoans and calcareous polychaeta worms [5]. The plastic fragments that serve as dispersion vehicles to invasive species [6] contain additives which can become biologically available when ingested by animals [7], such as pelagic and demersal fish [8], the Pacific anchovy (Engraulis mordax), oysters [9] or other commercialized shellfish, offering an increased risk to public health.

Plastic fragments as small as $20 \mu \mathrm{m}$ in diameter have been identified since the 1960's in increasing amounts. They occur both in the water column, among plankton, as well as in the sediment [10]. Besides the gradual decomposition by physical and mechanical factors in the marine environment, there might also be a contribution from plastic waste being deliberately reduced to small fragments and then discarded at sea [11].

The definition of microplastics is not fully consensual, with different size criteria to classify them, but they can be described as a heterogeneous mixture of plastic particles whose diameter ranges from a few microns up to several millimeters [12]. According to other authors [13], in this study we considered microplastic particles $<5 \mathrm{~mm}$ in diameter. Microplastics are differentiated into primary and secondary. These correspond to the degradation of larger plastic items into ever smaller particles, while the primary microplastics are produced into granules for direct use, or as precursors of other products, such as industrial abrasives or 
exfoliants, and plastic pellets [14] which are the focus of our study and are also named plastic beads, plastic granules, nurdles or mermaid tears. There are pellets of polyethylene $(\mathrm{PE})$, polypropylene (PP), polystyrene (PS), poly (vinyl chloride) (PVC) and poly (ethylene terephthalate) (PET) as well as other polymers less consumed. Generally pellets have spherical, ovoid, or cylindrical shapes, and commonly have clear, white or off-white colors [15]. They are easy to store, transport (usually packed in bags of $25 \mathrm{Kg}$ ) and process in conventional equipment such as extruders and injection molding machines.

Photo-oxidative, hydrolytic, mechanical and biological degradation processes occur in plastics exposed to the marine environment at different degradation rates [16]. The surface of eroded plastic pellets may serve as a substrate for deposition of insect larvae [17] and a hotspot for bacterial colonization [18]. Plastic pellets absorb and concentrate persistent organic pollutants (POPs), particularly polycyclic aromatic hydrocarbons (PAHs), polychlorinated biphenyls (PCBs) and dichloro-diphenyl-trichloroethane (DDT) [19]. Higher levels of adsorption of trace metals such as $\mathrm{Cr}$ and $\mathrm{Pb}$ were detected in PE pellets sampled in the beach environment and sediment from an estuarine region of southeast England, when compared to virgin pellets [20].

In the seawater, the electric surface charge of PE pellets is negative, hence eroded pellets are less favorable to concentrate hydrophobic compounds but more susceptible to interact with polar compounds such as paints, surfactants or metals existing in the water. Upon being ingested by marine organisms, pellets contact with stomach $\mathrm{pH}$, which can cause a reversal of their surface charge and thus a release of toxic compounds to the body [21]. The presence of plastic pellets in biota was registered, for example, in the digestive tract of sea birds, eight species of Procellariiformes [22] and the stomach contents of commercial or recreational fish species, like the Japanese anchovy (Engraulis japonicus) [23].

Whereas the negative aesthetic and economic impact of larger debris such as bags, bottles, cups, syringes, packaging plastics, ropes, nets, foams, etc., is automatically perceived by tourists, authorities, residents, local business, and environmental protection organizations, the same does not apply to plastic pellets, being a kind of solid waste of low visual impact, precisely because of their small size. It's identification and collection is not integrated in the marine and coastal cleaning routines, so it eventually accumulates and potentially leads to chronic contamination of these environments.

In Brazil, the scientific research on microplastics in the marine environment, particularly on plastic pellets, is not yet wide and consolidated. Studies reported the presence of such contaminants in the coast of Rio Grande do Sul [24], on Caiobá beach in Paraná [25]; [26], on beaches of the Bay of Santos in São Paulo [27], on Boa Viagem beach in Pernambuco [28] and on Fernando de Noronha Archipelago [29]. On the island of Santa Catarina, the presence of significant amounts of plastic pellets on Galheta beach was also reported [30]. One possible origin of these granules would be maritime transport. The fact that this debris were found in oceanic waters and coastal areas may be related to gaps in storage, logistics, land and sea transport of plastic pellets.

\section{Methodology}

This study intended to increase knowledge about plastic pellets occurrence in the Island of Santa Catarina (Brasil), testing hypotheses concerning its temporal and spatial variation concerning its abundance.

Since marine currents and other oceanographic variables, change seasonally, we expected to find significant seasonal variation in the abundance of plastics pellets. Similarly, we expected to find significant abundance variation between the sampled locations, since earlier observations suggested an uneven distribution of pellets on the beach, probably associated with small-scale oceanographic processes. In addition, we also expect to find a heterogeneous composition of the polymers.

To test the above mentioned hypothesis, we have chosen Campeche beach as sampling area (Fig. 1). This beach of easy access represents the east coast of Florianópolis, in the Island of Santa Catarina, a region exposed to the Atlantic Ocean.

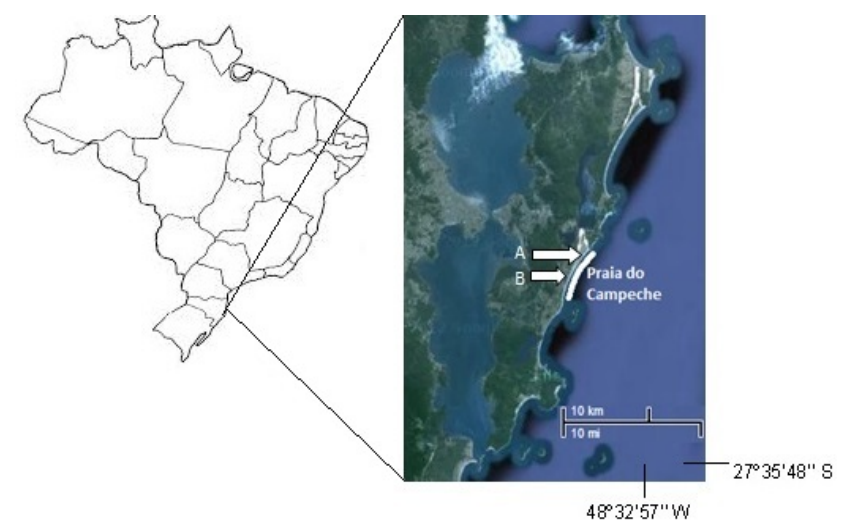

Figure 1. Monitoring Area in Campeche beach corresponds to the white beach $\operatorname{arc}$ between $\mathrm{A}$ and $\mathrm{B}$,

Three sampling events were held in each season, seeking to cover the beginning, middle and end of each season. Thus, 12 sampling events were undertaken between July 2011 and August 2012.

On every event two locations were sampled: one located about 750 meters south of the shore of Joaquina beach, herein called "A" and another located about 500 meters north of the village of Novo Campeche, herein called "B". At each location, a sampling unit $\left(1 \mathrm{~m}^{2}\right.$ of PVC pipe) was randomly released in ten replicates $(n=10)$ along the beach supralittoral compartment, between the beach berm and the frontal dunes.

In each sampling unit, plastic pellets were manually collected after a visual inspection of the area. In order to 
reduce a possible methodological bias, we did visual searches using a similar length of time, not exceeding 10 minutes for the search, within each sampling square.

Plastic pellets were counted and selected visually by color and shape. Their weight and diameter were obtained in laboratory with the aid of precision balance and caliper.

The identification of the polymers' composition of plastics pellets was based on its immersion in liquids with different densities: water; aqueous solution of isopropyl alcohol $(45,5$ vol.\%), and corn oil [31].

Data about the intensity and direction of the wind were recorded in the three preceding days and on the day of each sampling event [32]. Additionally, we also collected data about significant wave height, direction and wave peak period [33].

Data obtained from sampling were statistically analyzed, using analysis of variance.

\section{Results}

\subsection{Abundance}

Plastic pellets were found on the beach on every sampling day, totalizing 280 plastic pellets, and representing an average of 1,16 pellets $/ \mathrm{m}^{2}$. The average pellet weight was $0,0236 \mathrm{~g}$ and the average diameter was $4,07 \mathrm{~mm}$. Pellets were predominantly white or transparent. We observed that various pellets revealed an aged aspect due to weathering exposure, classifying it as yellowish white (Fig. 2i). About $50 \%$ of the plastic granules had cylindrical or ovoid shape. However, several granules presented a noticeable altered undefined shape caused by erosive and abrasive environmental processes (Fig.2ii).

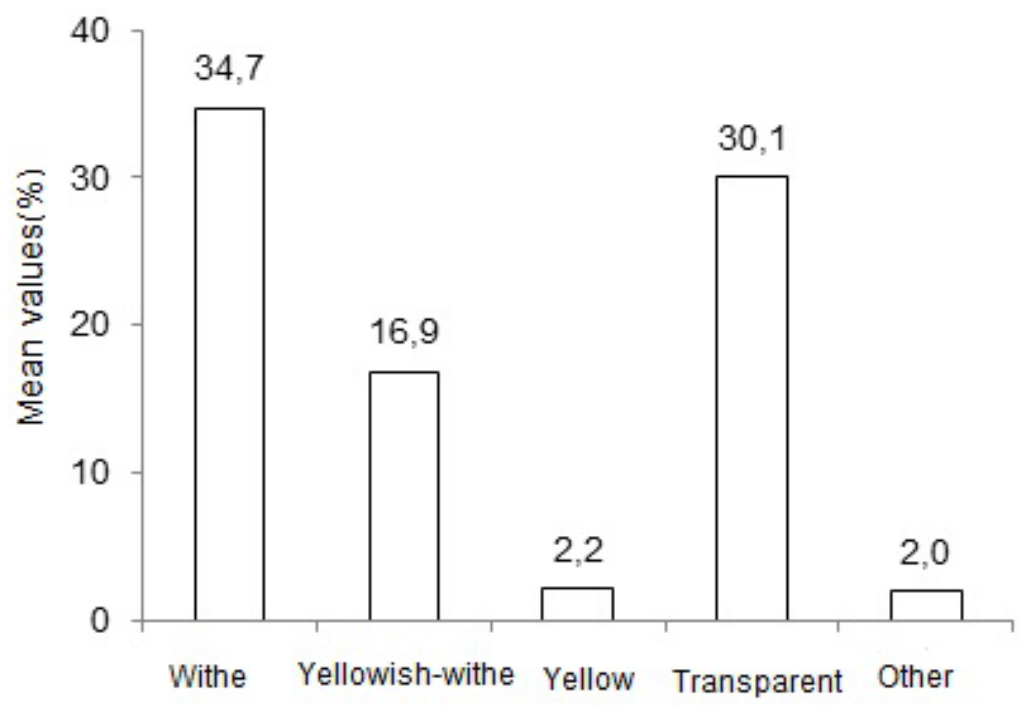

(i)

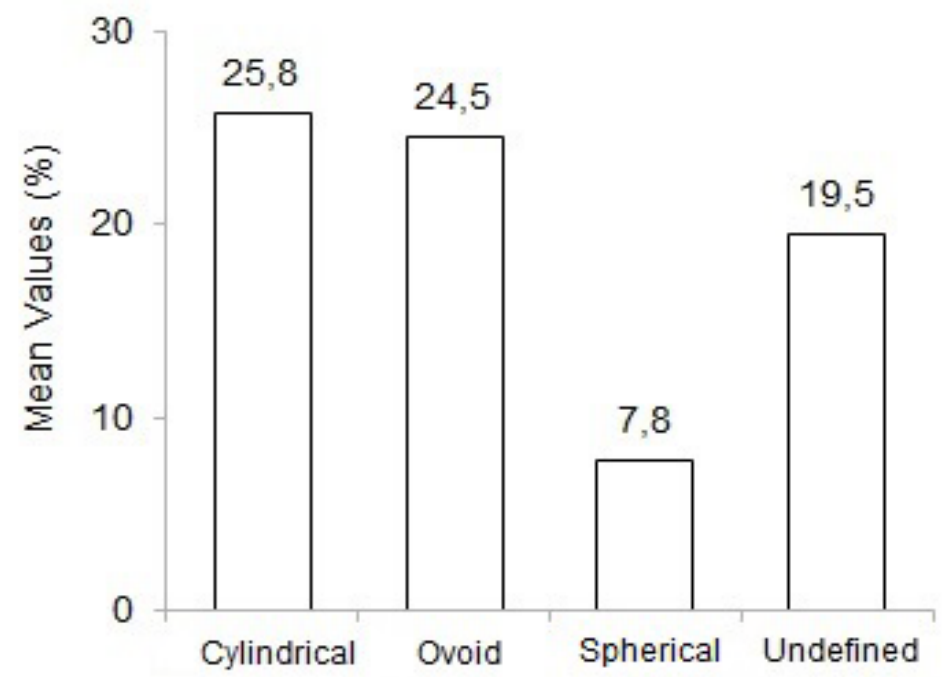

(ii)

Figure 2. Mean percentage values of colour (i) and shape (ii) prevalence of the plastic pellets 


\subsection{Spatial and Temporal Variation}

There was a considerable variation in the amount of pellets between the sampling locations and throughout the monitoring period.

The overall average of pellets $/ \mathrm{m}^{2}$ (mean \pm standard error), considering both locations, was $0,75 \pm 0,18$ in the winter; $0,80 \pm 0,19$ in the spring; $0,77 \pm 0,11$ in the summer and 2,35 $\pm 0,56$ in the autumn.

Although in the autumn the average abundance of pellets was about three times higher compared to other seasons, this difference is not statistically significant (Table 1) due to the large variation in the abundance of these pollutants between different days within the same season.

The number of pellets on the beach was influenced by an interaction between the Location and Sampling day factors, nested in each Season (Table 1). The explanation of a variable behaviour by one or more significant main factors alone is discarded when the analysis of variance detects a significant interaction between two or more factors [34].
Table 1. Analysis of variance with three factors

\begin{tabular}{|c|c|c|c|c|c|}
\hline Source & LD & MS & $F$ & $P$ & Significance \\
\hline Season & 3 & 37,36 & 2,87 & 0,1 & NS \\
\hline Day (Season) & 8 & 13,01 & 3,15 & 0,0022 & $* * *$ \\
\hline Location & 1 & 64,06 & 6,71 & 0,03 & $*$ \\
\hline Season x Location & 3 & 33,81 & 3,54 & & NS \\
\hline $\begin{array}{c}\text { Location x Day } \\
\text { (Season) }\end{array}$ & 8 & 9,5 & 2,31 & 0,02 & $*$ \\
\hline Residual & 216 & 4,13 & & & \\
\hline
\end{tabular}

Data were not transformed because no transformation was able to remove the heterogeneity of variances. Balanced ANOVA tests and a large number of replicates are robust to deal with this violation (Underwood, 1997). NS = Non Significant; $*=\mathrm{P}<0,05 ; * *=\mathrm{P}<0,01 ; * * *=\mathrm{P}<0,001$.

The abundance of plastic pellets in this study was influenced by an interaction between location and day of the season.

In the winter, the abundance of pellets was significantly higher in location $\mathrm{B}$, on the $2^{\text {nd }}$ sampling day.

In the spring, the abundance of pellets was significantly higher in location $\mathrm{A}$, on the $3^{\text {rd }}$ sampling day.

In the summer, there were no significant differences in terms of pellet abundance, between the two locations.

In the autumn, the abundance of pellets was significantly higher in location $\mathrm{A}$, on the $1^{\text {st }}$ and $3^{\text {rd }}$ sampling days (Fig. 3).
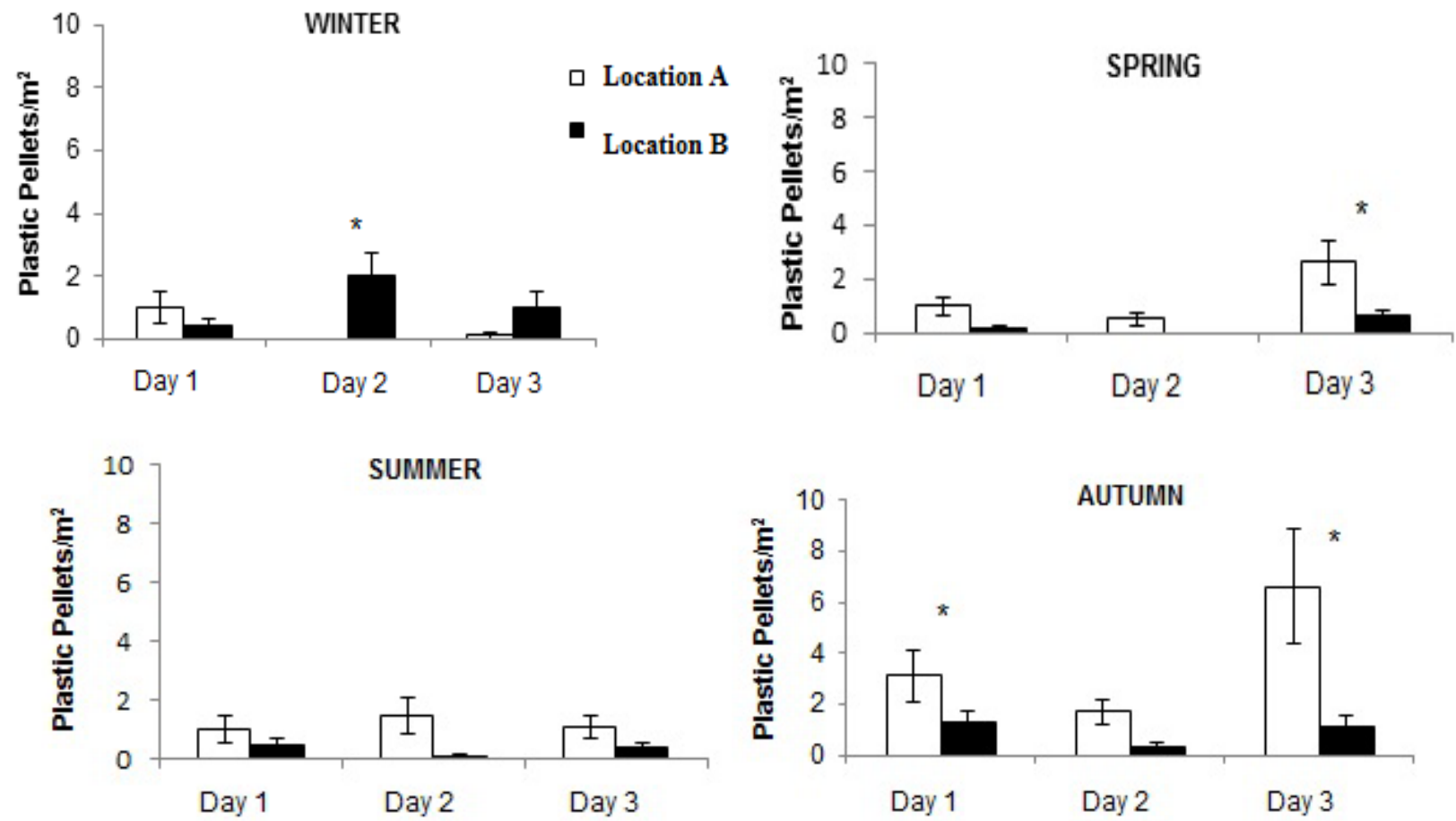

Figure 3. Spatial and temporal variation of the plastic pellets. Columns show the mean value and bars indicate standard error. The symbol $*$ indicates a significant difference to the level of $\mathrm{P}<0.05$ (paired tests SNK). 
Although not representing a consistent pattern over all sampling dates, the mean average abundance of pellets per square meter was significantly higher at location A $(1,28 \pm$ $0,27)$, compared to location $\mathrm{B}(0,65 \pm 0,10)$, as displayed in Figure 4.

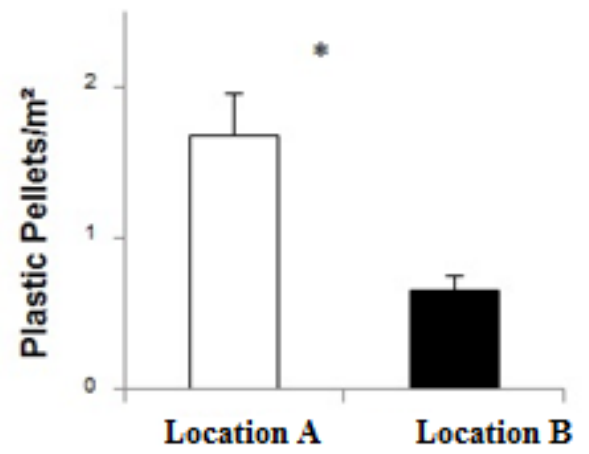

Figure 4. Variation of the abundance of plastic pellets, between sampling locations

It is worth mentioning the existence of a "hotspot" of pellet deposition near location A. This spot was not part of the sampling design, but we noticed vast amounts of plastic granules accumulated in this area throughout the year.

\subsection{Oceanographic Factors}

Wind direction varied greatly during winter samplings. For example, during the $3^{\text {rd }}$ sampling period there were East, Northeast and Southeast winds, blowing with intensities, between 30 and $40 \mathrm{~km} / \mathrm{h}$. During spring samplings, winds were predominantly coming from north-northeast, with lower intensities from 10 to $20 \mathrm{~km} / \mathrm{h}$ (Table $2 \mathrm{i}$ ).

We also recorded the variability of the wave's height and direction. In the summer, for example, Southeast and East waves prevailed in the $1^{\text {st }}$ and $3^{\text {rd }}$ samplings whilst in the $2^{\text {nd }}$ sampling waves came from East-Northeast (Table 2ii). In the autumn, in the $1^{\text {st }}$ and $3^{\text {rd }}$ samplings, South direction waves prevailed, and during the $2^{\text {nd }}$ sampling waves came from the East-Southeast.

Table 2. Oceanographic factors

(i) Intensity of the average wind $(\mathrm{km} / \mathrm{h})$ and the mean wind direction in the days leading up to and on days of spring samples

\begin{tabular}{|c|c|c|}
\hline Spring Sampling & $\begin{array}{c}\text { Intensity of the } \\
\text { average wind }(\mathrm{km} / \mathrm{h})\end{array}$ & Wind direction \\
\hline Three days before & $15-20$ & $\mathrm{NE}$ \\
\hline Two days before & $10-15$ & $\mathrm{~N}$ \\
\hline One day before & $15-20$ & $\mathrm{NE}$ \\
\hline $1^{\text {st }}$ Sampling & - & - \\
\hline Three days before & $20-25$ & $\mathrm{~N}$ \\
\hline Two days before & $15-20$ & $\mathrm{~N}$ \\
\hline One day before & $15-20$ & $\mathrm{NE}$ \\
\hline $2^{\text {nd }}$ Sampling & $10-15$ & $\mathrm{SW}$ \\
\hline Three days before & $10-15$ & $\mathrm{E}$ \\
\hline Two days before & $15-20$ & $\mathrm{~N}$ \\
\hline One day before & $10-15$ & $\mathrm{NE}$ \\
\hline $3^{\text {rd }}$ Sampling & $10-15$ & $\mathrm{~N}$ \\
\hline
\end{tabular}

(ii) Significant wave height (meters) and direction, in the days leading up to and on the days of summer samplings.

\begin{tabular}{|c|c|c|}
\hline Summer Sampling & $\begin{array}{c}\text { Wave significant } \\
\text { height }(\mathrm{m})\end{array}$ & Wave direction \\
\hline Three days before & 2 & SE-S \\
\hline Two days before & 1,75 & SE-S \\
\hline One day before & 1,5 & SE \\
\hline $1^{\text {st }}$ Sampling & 1,5 & E-SE \\
\hline Three days before & 1,7 & NE-E \\
\hline Two days before & 1,25 & NE-E \\
\hline One day before & 1,1 & NE-E \\
\hline $2^{\text {nd }}$ Sampling & 0,8 & E \\
\hline Three days before & 1,3 & E-SE \\
\hline Two days before & 1,4 & SE \\
\hline One day before & - & - \\
\hline $3^{\text {rd }}$ Sampling & 1,6 & S-SE \\
\hline
\end{tabular}

\subsection{Chemical Composition of the Polymers}

We found a heterogeneous composition of the polymers which constitute the sampled pellets. The majority (53\%) were composed of low density polyethylene (LDPE). Polypropylene (PP) and high density polyethylene (HDPE) were also pellet components (Fig. 5).

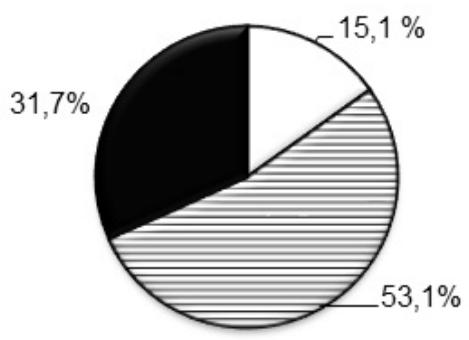

口HDPE घLDPE aPP

Figure 5. Composition of the sampled plastic pellets. Polymer composition of the sampled plastic pellets (percentage values). HDPE = high density polyethylene; LDPE = Low density polyethylene; $\mathrm{PP}=$ Polypropylene

\section{Discussion}

\subsection{Abundance}

Although in the present study we found plastic pellets on every sampling day, which is worrying, the mean value observed is relatively low when compared to other studies. In this study there was an average of 1,16 pellets $/ \mathrm{m}^{2}$. However, if the whole beach area was sampled - approximately 4.500 meters length and 20 meters width - we estimate that about 104.400 pellets could be found only at the surface of the beach, disregarding all plastic material that can be found buried at various depths. In other studies plastic pellets were also found at depths up to 2 meters, suggesting that three-dimensionality should be considered when performing 
sampling to a depth where there is the presence of plastic pellets, in order to estimate more accurately the amount of such plastic waste on the beaches [35].

Densities between 1.000 and 1.800 pellets per linear meter were reported on beaches located near the city of Port Elizabeth, Eastern Cape - South Africa, where industries of plastics, tires and automotive parts are concentrated, and also reported densities of 1.500 up to 10.000 pellets per linear meter, carried by a coastal stream that flows from east to Woody Cape, part of the Greater Addo National Park [36]. Plastic pellets found on the beach of Boa Viagem, Recife, with a concentration of 10 pellets $/ \mathrm{m}^{2}$ accounted for $3,3 \%$ of the total sampled plastic items, probably from sea or port sources, as there are no records of petrochemical complexes or pellet processing plants at this location [37].

In this sense, the present study serves as an advice to the social actors responsible for the management of local beaches, as well as to the economic sectors of production, transport and processing of these plastic granules. Since the level of contamination observed in the studied area is still low, it is the right time to make management decisions to reduce the problem and to prevent it. Moreover, nothing suggests that the observed contamination is restricted to the studied beach. Considering that the transport of pellets in the environment is mediated by wind, currents and waves, it is quite likely that other beaches on the east coast of Santa Catarina Island are also contaminated.

\subsection{Spatial and Temporal Variation}

In this study we recorded a great variability of the abundance of plastic pellets in each location, among different days within the same season, and also between two locations in the same day. These variations were of such magnitude that made the observed seasonal variation statistically not significant. Several other papers around the world have also shown great variability in the abundance of these contaminants. The presence of an average of 54 pellets $/ \mathrm{m}^{2}$ sampled at Japanese beaches and absence of these granules in sampled beaches of Russia, was surprising, given that even remote areas of the Southern Pacific are polluted by plastic pellets [38]. A variation in the abundance of plastic pellets among seasons was studied in Santos cove, São Paulo, and no clear pattern was observed in the input rates of plastic pellets throughout the year. The largest number of granules occurred in the winter $\left(377 / \mathrm{m}^{2}\right)$ after a storm event, at the upper portions of the sediment, suggesting that extreme events quickly remobilize and redeposit the sediment, trapping plastic pellets. Anthropic processes such as sand disturbance by tractors can also influence the abundance of pellets at the uppermost portions of the sediment [39].

Variations registered on a scale of days and between locations disclosures the complexity of trying to make generalizations about the level of contamination of a whole beach. Our study suggests that, instead of seeking to establish an average amount of pellets for the entire
Campeche beach, it is more appropriate to refer to the abundance of pellets on a stretch of beach within a few hundred meters, on a given day. Other stretches of the same beach, or even the same stretch on another day, may present different abundances. Hence, the small scale variation of pellet distribution in hundreds of meters, found in our study, has significance when compared with conventional studies, which analyze pellet distribution, in a range of kilometers or hundreds of kilometers.

Our study intended to analyze eventual patterns, without the pretention of testing processes. Once we found this small scale variation pattern, we can now explore the processes, or causes of this variation. The causes could be related with oceanographic variations, also in a small scale, like beach orientation, beach face slope, wave incidence, depositional processes, among other factors that may also vary in such a small scale.

Acknowledging the limitation of having only two study locations, which corresponds to the exploratory and initial profile of our research on pellet distribution, we recommend that future studies would include a higher number of locations, having in mind the small scale variation pattern we found during our monitoring period and thus testing possible pattern similarities in other beaches and coastal regions.

\subsection{Oceanographic Factors}

We could not find a clear relationship between the abundance of plastic pellets and the patterns of winds and waves recorded for the days near the sampling events. In the days leading up to the $3^{\text {rd }}$ sampling day of Spring season, in which we found a significantly higher abundance of pellets in location A, the waves came from Southeast-East, then from East-Northeast on the sampling day. This greater amount of pellets does not appear to have been influenced solely by the oceanographic factors, since throughout the sampling period of spring, North quadrant winds predominated.

The largest abundance of plastic pellets was recorded in location $\mathrm{A}$, in the $1^{\text {st }}$ and $3^{\text {rd }}$ autumn samplings days. This could be related to the predominance of waves coming from the south during this sampling period, and the prevailing southern quadrant winds that occurred in the days preceding and on the $3^{\text {rd }}$ sampling day. Although there were northern quadrant winds in the days previous to the 1 st sampling, on that sampling day the prevailing winds came from southeast.

Overall, the greater occurrence of plastic pellets in location A may be associated with the typical longshore current and southerly winds, favoring the deposition processes in that portion of the beach arc. This process is supported by the observation of a greater length and a smaller slope of the beach in location A.

At Fernando de Noronha Archipelago, plastic granules were found on beaches of the windward side, exposed to the open ocean and as such, subject to the action of the anti-clockwise South Atlantic gyre, highlighting the role of 
surface currents in marine debris transport [40]. The explanatory model of deposition of plastic pellets could be similar to that of quartz, mica, and other grains because the plastic granules have lower densities than the sediment and its hydraulic equivalent differs from sandy sediment, however, it is possible that after storm events, followed by wind action, pellets accumulate in the uppermost regions of the beach and get buried [41]. This may explain the large accumulation (hotspot) of pellets we noticed near location A, throughout the monitoring period, because that is an upper region of the beach, favorable to accumulation of that debris. The results of this study are compatible, therefore, with the idea of the pattern of distribution of plastic waste being associated with its entry points in the environment, such as urban areas or commercial routes, and also being influenced by winds and currents and coastal geography [42].

\subsection{Chemical Composition of Polymers}

The samples collect over the monitoring period clearly indicate a greater abundance of pellets composed of LDPE. This material is suitable for manufacturing films, packaging, milk bags, plastic bags, disposable diapers, wire and cable coverings. Whilst PP, the second most abundant polymer, is used to produce plastic water glasses, margarine pots, sterile hospital supplies, parts for washing machines, and a large number of automobile interior parts. Toys, buckets, pipes for water and gas distribution, packaging for pesticides and fruit packaging nets, are examples of plastic products made from HDPE.

Plastic granules composed of PP, HDPE and LDPE and PS and other microplastics were also described on sampled beaches, from north to south of Portugal [43].

Despite of the existence of an eclectic variety of thermoplastics, those called commodities - PE, PP, PS, PVC, and PET - account for about $90 \%$ of Brazilian consumption, and surveys in large cities, point out especially PE, PET and PVC as main polymers found in municipal solid waste [44]. Additionally, many plastic packaging are produced using different polymers. For example, detergent bottles, cleaning products and toiletries can be produced with LDPE, HDPE or PP granules. Garbage bags are also made of LDPE, HDPE or PVC. In a single packaging PET bottle for soft drinks, there are several different types of plastics: HDPE label, PP cap and ethylene vinyl (poly) acetate (EVA) seal [45].

All these above mentioned factors allow us to associate the heterogeneous composition of the plastic pellets analyzed during the monitoring period at Campeche beach, with the diversification of polymer applications to an extensive scope of plastic products, and with the multiplicity of sources of plastic pollution of the southern Brazilian coast due to various dispersion mechanisms.

In fact, the Southeast of Brazil concentrates the majority of plastic pellets production plants, being $78 \%$ of the production destined for internal consumption [46]. There are more than 11.600 companies of plastic pellet transformation, located throughout the country, mostly in the south and southeast [47]. In Santa Catarina, this industry is concentrated mainly in three regions: in the north of the state, with plastic production for civil construction and technical pieces; in the south, with production of disposable plastics; and in the wide urban area of Florianópolis which comprises the municipalities of Florianópolis, São José, Palhoça and Biguaçu. In this urban area there are records of 35 manufacturing plants, 11 of them directed to the production of plastic packaging [48].

The accidental or intentional loss of pellets during coastal shipping, or land transport, to supply the packaging industries located in the wide urban area of Florianópolis can be cited as plausible origins of the plastic pellets found in this monitoring. However, remote sources associated with national and intercontinental sea shipping, also deserve to be considered, since the plastic pellets shipping reveals an upward trend in terms of export, along fourteen ports of the Brazilian coast, with greater concentration in the South and Southeast [49].

\section{Final Considerations}

In the 1990s, about 20 to 30 years after the presence of plastic granules was confirmed in the marine environment, the US Environmental Protection Agency recommended the plastics manufacturing industry to revise a number of procedures to avoid loss of these granules into the environment. An environmental protection commitment was established for retaining granules and stressed the importance of educating employees to prevent losses, to monitor critical points of the production line, to vacuum or regularly sweep the lost granules and recycle them, to use more resistant packaging and inspect the cargo vehicles, and to draw up a checklist to verify the correct application of routine [50].

Pellets that were packed in cardboard boxes or less resistant plastic bags are now packed in stronger bags and placed inside containers minimizing losses.

The production of plastic pellets totalizes 250 million tons worldwide, with Brazil accounting for the production of 6,5 million tons, equivalent to $2,7 \%$ of world production, leading the production in Latin America [51]. Towards this huge amount globally produced, the economic value of pellet loss could seem relatively negligible, but unlike larger marine debris, the removal of micro polluting materials from the marine environment - including plastic pellets - is currently not feasible from the technical and economical point of view. Thus, and given the abundance of this material found not only in Brazil but on beaches around the world, it remains highly recommended to invest in pollution prevention by improving the methods of production, logistics of distribution and land and port transportation of these materials.

Once introduced into the environment, the fate of these 
residues, although unclear, is undoubtedly generating concern. Therefore it is important to consider the environmental, economic and social costs.

We consider important to study plastic pellets distribution on the beaches, since the majority of the studies in the literature focus on other categories of marine litter, and in Latin America this studies are even scarcer. The characterization of the seasonal variability and the type of polymers that compose the plastic pellets found on Campeche beach is an initial tool in the search for solutions to tackle locally this source of marine pollution and improve coastal management in Santa Catarina Island and along the Brazilian coast. But the study of this material, should also relate to the investigation of habitat colonization by invasive species, biodiversity threats, health risks, a range of issues that arises serious concerns to researchers, nongovernmental and governmental organizations and citizens.

The group of experts on scientific aspects of marine environmental protection [52] recognizes the limitation of knowledge about the processes that occur over time during the permanence of plastic debris in the marine environment and emphasizes the need for the involvement of all stakeholders, in order to monitor the movements of these plastic items, their accumulation, degradation, ingestion by marine organisms and effects on coastal and open sea areas.

At the $5^{\text {th }}$ Global Conference on Marine Debris, held in Honolulu [53], experts defined a strategy to reduce the quantities and impacts of debris, coming from land-based sources, from marine sources, accumulated in coast line, benthic environments and water column. Among the waste monitoring indicators from land-based sources set out in this strategy it is mentioned: the evaluation of the plastic pellet loss rate, which eventually reaches the oceans; the voluntary participation in control efforts to prevent it, such as Operation Clean Sweep program implemented by the plastics industry in North America and the United Kingdom; and the development and implementation of regulatory measures whenever volunteer programs are not effective.

In view of the paradox of growing market demand for practical and disposable products, contrasting to attitudes and lifestyle habits that promote more sustainable consumption patterns, it is also noted the importance of working the issue of discarding plastic products . This should happen through the implementation and enforcement of legislation involving reverse logistics and circular economy by companies, also through the design and implementation of prevention and control strategies by health and environmental authorities, the involvement of local communities, tourism agencies, media, as well as a strong incentive for environmental education, research and collaboration of the scientific community.

\section{REFERENCES}

[1] Andrady, A.; Neal, M. Applications and societal benefits of plastic. 2009. Phil. Trans. Soc. B 364, 1977-1984.
[2] British Plastic Federation, 2013. http://www.bpf.co.uk

[3] Plastics Europe, 2016. Plastics - the Facts 2016. An analysis of European plastics production, demand and waste data. http://www.plasticseurope.org/Document/plastics---the-facts2016-15787.aspx?Page=DOCUMENT\&FolID=2.

[4] Costa, M. F.; Araújo, M.C.B.; Ivar do Sul, J.A.; Silva-Cavalcanti, J.S.; Sant'Anna Jr., N. Poluição Marinha Principais Aspectos. Recife, 2015.

[5] Widmer, W. M. Recreational boating as a contributing source of marine debris, and their fouling assemblages. In: Saxena, N. K. (Editor). Recent Advances of Marine Science and Technology, 2002. Pacon International, Honolulu. 2003.

[6] Barnes, D.K.A., 2002. Invasions by marine life on plastic debris. Nature, 416, 808-809.

[7] Ogata Y1, Takada H, Mizukawa K, Hirai H, Iwasa S, Endo S, Mato Y, Saha M, Okuda K, Nakashima A, Murakami M, Zurcher N, Booyatumanondo R, Zakaria MP, Dung le Q, Gordon M, Miguez C, Suzuki S, Moore C, Karapanagioti HK, Weerts S, McClurg T, Burres E, Smith W, Van Velkenburg M, Lang JS, Lang RC, Laursen D, Danner B, Stewardson N, Thompson RC. International Pellet Watch: Global monitoring of persistent organic pollutants (POPs) in coastal waters. 1 . Initial phase data on PCBs, DDTs, and HCHs. Marine Pollution Bulletin. Volume 58, Issue 10, 1437-1446 (2009).

[8] Lusher, A.L.; McHugh, M.; Thompson, R.C. Occurrence of microplastics in the gastrointestinal tract of pelagic and demersal fish from the English Channel. Mar. Pollut. Bull. (2012).

[9] Rochman C., Hoh, E., Hentschel, B., Kaye, S. Anthropogenic debris in seafood: Plastic debris and fibers from textiles in fish and bivalves sold for human consumption. 2015. Scientific Reports | 5:14340 | DOI: 10.1038/srep14340.

[10] Thompson, R.C.; Olsen, Y; Mitchell, R.P; Davis, A.; Rowland, S.J.; John, A.W.G.; Mcgonigle, D.; Russell, A.E. Lost at sea: where is all the plastic? Science, 304, 838. 2004.

[11] Barnes, D.K.A.; Galgani, F.; Thompson, R.C.; Barlaz, M. Accumulation and fragmentation of plastic debris in global environments. Phil. Trans. R. Soc. B. 2009- 364, 1985-1998.

[12] Thompson, R.C. 2015. Microplastics in the marine environment: Sources, Consequences and solutions. (Chapter 7). p. 185-200. In: Bergmann, M.; Gutow, L. \& Klages, M. (editors). Marine Anthropogenic Litter. SpringerOpen: Bremerhaven.

[13] Galgani, F., Fleet, D., Van Franeker,J., Katsanevakis, S., Maes, T., Mouat, J., Oosterbaan, L., Poitou, I., Hanke, G., Thompson, R., Amato, E., Birkun, A., Janssen, C. Marine strategy framework directive. Task Group 10 Report Marine litter. Editor: N. Zampoukas. EUR 24340 EN - 2010.

[14] Arthur, C.; Bake, J; Bamford, H. (eds). 2009. Proceedings of the International Research Workshop on the Occurrence, Effects and Fate of Microplastic Marine Debris. Sept 9-11, 2008. NOAA Technical Memorandum NOS-OR\&R-30.

[15] United States Environmental Protection Agency- US EPA. Plastic pellets in the aquatic environment. Sources and recommendations- a summary. 1993.

[16] Andrady, A.L. Microplastics in the marine environment. Marine Pollution Bulletin 62 (2011) 1596-1605. 
[17] Majer, A.P.; Vedolin M.C.; Turra, A. Plastic pellets as oviposition site and means of dispersal for the ocean-skater insect Halobates. Marine Pollution Bulletin 64 (2012) 11431147.

[18] Harrison, J.; Sapp, M.; Schratzberger, M.; Osborn, A.M. Interactions Between Microorganisms and Marine Microplastics: A Call for Research. Marine Technology Society Journal, Volume 45 Number 2. 2011.

[19] Frias, J.P.G.L.; Martins, J.; Sobral, P. Investigação sobre detritos marinhos plásticos em Portugal continental. Revista da Gestão Costeira Integrada 11(1):145-148 (2011).

[20] Holmes, L.A.; Turner, A.; R. C. Thompson. Adsorption of trace metals to plastic resin pellets in the marine environment. Environmental Pollution 160 (2012) 42-48.

[21] Kalliopi, N.F.; Karapanagioti, H.K. Surface properties of beached plastic pellets. Marine Environmental Research 81 (2012) 70-77.

[22] Colabuono, F.I.; Taniguchi, S.; Montone, R.C. Polychlorinated biphenyls and organochlorine pesticides in plastics ingested by seabirds. Marine Pollution Bulletin 60 (2010) 630-634.

[23] Tanaka, K. and Takada, H. Microplastic fragments and microbeads in digestive tracts of planktivorous fish from urban coastal waters. www.nature.com/scientificreports. 2016.

[24] Pianowsky, F. Resíduos sólidos e esférulas plásticas nas praias do Rio Grande do Sul - Brasil. Monografia apresentada à Universidade do Rio Grande. 1997.

[25] Nascimento, A. A.; Widmer, W. M. Ocorrência de grânulos plásticos e outros itens de pequenas dimensões na praia Brava de Caiobá - Matinhos/PR. In: Anais do Encontro nacional de gerenciamento costeiro (ENCOGERCO), Rio de Janeiro, 2009. Agência Nacional de Gerenciamento Costeiro (GERCO).

[26] Fontenelle, F. R. Determinação de poluentes orgânicos persistentes aderidos a grânulos plásticos depositados em praias do litoral paranaense. Trabalho de Conclusão de Curso (Bacharelado). Centro de Estudos do Mar - UFPR. 2011.

[27] Fisner, M.; Tanigushi, S.; Majer, A.; Bícego, M.; Turra, A. Concentration and composition of polycyclic aromatic hydrocarbons (PAHs) in plastic pellets: Implications for small-scale diagnostic and environmental monitoring. Marine Pollution Bulletin 76, p.349-354. 2013.

[28] Costa, M.F.; Ivar do Sul, J.A.; Silva-Cavalcanti, J.S.; Araújo, M.C.B.; Spengler, A. On the importance of size of plastic fragments and pellets on the strandline: a snapshot of a Brazilian beach. Environ Monit Assess. 2009. DOI 10.1007/s10661-009-1113-4.

[29] Ivar do Sul, J. A.; Spengler, A.; Costa, M. F. Here, there and everywhere. Small plastic fragments and pellets on beaches of Fernando de Noronha (Equatorial Western Atlantic). Mar. Pollut. Bull., v. 58, p. 1229-1244 (2009).

[30] Widmer, W. M.; Hennemann, M. Marine debris in the island of Santa Catarina, South Brazil: Spatial patterns, composition and biological aspects. Journal of Coastal Research 26(6), 993-1000. 2010

[31] Katz, D.A. Identification of polymers. http://www.chymist.com/polymeridentification.pdf In: Kollman C.S. (1994) Chem 13 News. 1998.
[32] Centro de informações de recursos ambientais e de hidrometeorologia de Santa Catarina- Ciram, 2011, 2012. http://ciram.epagri.sc.gov.br

[33] Centro de previsão de tempo e estudos climáticos- CPTEC, 2012. http://www.cptec.inpe.br/

[34] Underwood, A. J. Experiments in Ecology. Their logical design and interpretation using analysis of variance. Cambridge University Press, Cambridge (UK). 1997

[35] Turra, A. ; Manzano, A. B. ; Dias, R.J. ; Mahiques, M. M. ; Barbosa, L.; Balthazar-Silva, D.; Moreira, F. Three-dimensional distribution of plastic pellets in sandy beaches: shifting paradigms. Scientific Reports, v. 4,p. 1, 2014. DOI: http://www.nature.com/articles/srep04435.

[36] Ryan, P.G., et al. Long-term decreases in persistent organic pollutants in South African coastal waters detected from beached polyethylene pellets. Mar. Pollut. Bull. (2012).

[37] Costa, M.F.; Ivar do Sul, J.A.; Silva-Cavalcanti, J.S.; Araújo, M.C.B.; Spengler, A. On the importance of size of plastic fragments and pellets on the strandline: a snapshot of a Brazilian beach. Environ Monit Assess. 2009. DOI 10.1007/s10661-009-1113-4.

[38] Kusui, T.; Noda, M.. International survey on the distribution of stranded and buried litter on beaches along the Sea of Japan. Mar. Pollut. Bull., v. 47, p.175-179 (2003).

[39] Manzano, A.B. Distribuição, taxa de entrada, composição química e identificação de fontes de grânulos plásticos na Enseada de Santos, SP, Brasil. Dissertação apresentada ao Instituto Oceanográfico da Universidade de São Paulo, 2009.

[40] Ivar do Sul, J. A.; Spengler, A.; Costa, M. F. Here, there and everywhere. Small plastic fragments and pellets on beaches of Fernando de Noronha (Equatorial Western Atlantic). Mar. Pollut. Bull., v. 58, p. 1229-1244 (2009).

[41] [41] Dias, R. J. S.; Mahiques, M. M.; Turra, A.; Santos, J. F. C. Correlação entre depósitos de minerais pesados e plastic pellets na coluna sedimentar da praia de Santos. XIV Congresso Latino-Americano de Ciências do Mar - XIV COLACMAR Balneário Camboriú (SC / Brasil). 2011.

[42] Barnes, D.K.A.; Galgani, F.; Thompson, R.C.; Barlaz, M. Accumulation and fragmentation of plastic debris in global environments. Phil. Trans. R. Soc. B. 2009- 364, 1985-1998.

[43] Sobral, P.; Frias, J.; Martins, J. Microplásticos nos oceanos um problema sem fim à vista. Ecologi@ 3: 12-21 (2011).

[44] Spinacé, M.A.S.; De Paoli, M.A. A tecnologia da reciclagem de polímeros. Química Nova, v. 28, p. 65-72. 2005.

[45] Kipper, L.; Mählmann, C.M.; Rodríguez, A.L. Ações estratégicas sistêmicas visando à integração da cadeia produtiva e de reciclagem de plásticos. Associação Brasileira de Engenharia de Produção - ABEPRO. Universidade Federal de Santa Catarina - UFSC www.producaoonline.org.br ISSN 1676 - 1901 / Vol. IX/ Num.IV/ 2009.

[46] Pereira, F. Microplásticos no ambiente marinho: mapeamento de fontes e identificação de mecanismos de gestão, para minimização a perda de pellets plásticos. Dissertação apresentada ao Instituto Oceanográfico de São Paulo, 2014.

[47] ABIPLAST, Indústria Brasileira do plástico. Perfil. 
2014.http://file.abiplast.org.br/download/links/2015/perfil a biplast_2014_web.pdf

[48] Fachin, A.L.; Almeida, C.C.R.; Cario, S.A.F. Análise das condições competitivas da indústria de materiais plásticos de Santa Catarina: um estudo no segmento de embalagens plásticas da Grande Florianópolis. Cadernos de Economia Curso de Ciências Econômicas - Unochapecó. Ano 12, n. 23. 2008.

[49] Pereira, F. Microplásticos no ambiente marinho: mapeamento de fontes e identificação de mecanismos de gestão, para minimização a perda de pellets plásticos. Dissertação apresentada ao Instituto Oceanográfico de São Paulo, 2014.

[50] United States Environmental Protection Agency- US EPA. Plastic pellets in the aquatic environment. Sources and recommendations- a summary. 1993.

[51] ABIPLAST, Indústria Brasileira do plástico. Perfil. 2014.http://file.abiplast.org.br/download/links/2015/perfil_a biplast_2014_web.pdf

[52] GESAMP (Joint Group of Experts on the Scientific Aspects of Marine Environmental Protection); Bowmer, T. and Kershaw, P.J., 2010 (Eds.), Proceedings of the GESAMP International Workshop on plastic particles as a vector in transporting persistent, bio-accumulating and toxic substances in the oceans. GESAMP Rep. Stud. No. 82, 68pp.

[53] NOOA, UNEP The Honolulu Strategy, a Global Framework for Prevention and Management of Marine Debris. Honolulu, Hawaii, 2011. 